\title{
Gender Differences in the Relationship between Competitiveness and Adjustment among Athletically Identified College Students
}

\author{
Michele M. Carter, Carol S. Weissbrod \\ Department of Psychology, American University, Washington, DC., USA. \\ Email: mcart@american.edu \\ Received November $12^{\text {th }}, 2010$; revised January $12^{\text {th }}, 2011$, accepted January $20^{\text {th }}, 2011$
}

\begin{abstract}
This study explored the relationship between gender and enjoyment of competition and various indicators of mental health and adjustment in a sample of college students who report that they highly value athletics. One hundred and thirty-seven students completed the Sports Anxiety Scale, Multi-perfectionism Scale, State-Trait Anxiety Inventory (Trait), Beck Depression Inventory, and Perception of Competition Scale. Results indicated that among women, enjoyment of competition was associated with decreased levels of athletic anxiety and a positive correlation between positive self-perception when winning and self-and socially oriented perfectionism, and between negative perception when losing and self-and socially oriented perfectionism. Among males, enjoyment of competition was related to decreased levels of general anxiety and depression, but not athletic anxiety. Furthermore, among men there was a positive correlation between enjoying competition and self-oriented perfectionism and between negative self-perception when losing and socially-oriented perfectionism. These data indicate gender differentially impacts the benefit of valuing athletics on measures of athletic anxiety and general measures of psychological well being.
\end{abstract}

Keywords: Gender Differences, Athletic Identification, Competitiveness, Adjustment

\section{Introduction}

Interest in college students' health and activity are important topics as they relate to well-being and adjustment (Montgomery \& Côté, 2003). One activity that now holds value for many students is athletics. Although interest in athletics has historically involved men more than women, since Title IX, an increasing number of women have valued athletics in their lives (Gill, 2001). Researchers have wondered about the potential health and performance outcomes for older adolescents who value athletics and/or compete (Carodine, Almond, \& Gratto, 2001; Fletcher, Benshoff, \& Richburg, 2003; Weiss, 2004). Steiner and colleagues (2000), for example, found evidence of increased mental health benefits (as measured by a general measure of psychological health) among high school students. Further, Melendez (2006) found that athletic participation was related to academic and institutional adjustment is a sample of college students. The former, however, did not examine gender differences and neither study assessed the impact of enjoying competition on psychological functioning. We address these issues by assessing men's and women's enjoyment of competition, sport-specific and general anxiety, perfectionism and depression in a sample of students who report that athletics is important to them. Particularly since it has been found that whether an individual succeeds or fails at activities important to them can produce significant variation in self esteem (Crocker, Sommers, \& Luhtanen, 2002; Crocker, Karpinski, Quinn, \& Chase, 2003).

Arnett (2000) described the period of time between the ages of 18 and 25 as a period of "emerging adulthood," during which students engage in extended self exploration. During this period, it is often the case that students also experience anxiety as they explore various features of themselves and are evaluated in their various pursuits Arnett, 2007). Of interest in this study are factors that could influence whether athletic interest contributes to personal adjustment in college. When athletic interest involves individual competitiveness, for example, it has been found that some aspects of competitiveness, (e.g., when individuals focus on enjoyment and task mastery) can be facilitative of identity development and adjustment (Ryckman, Hammer, Kaczor, \& Gold, 1996). Personal development competitive attitude does not by definition exclude the desire to win, but operates in contrast to "hypercompetitiveness," or a win-at-all cost attitude that has been associated with neuroticism and poor adjustment (Ryckman, Libby, van den Borne, Gold, \& Lindner, 1997; Ryckman, Thornton, \& Butler, 1994). In addition to competitiveness, factors such as gender and concern about evaluation issues (i.e., perfectionism) may be related to adjustment among students who value athletics.

Researchers have consistently reported that participating in sports has been more important to boys than to girls in childhood (Eccles, Wigfield, Harold, \& Blumenfeld, 1993; Fredricks \& Eccles, 2005; Wigfield, Eccles, Yoon, Harold, Arbreton, Freedman-Doan, \& Blumenfeld, 1997) and adolescence (Eccles \& Harold, 1991). Yet, it has been shown that women report more competitive anxiety than men (Lorimer, 2006; Wong, Lox, \& Clark, 1993) and often underestimate their abilities in competitive situations (Corbin, 1981). Explored in the current study is the issue of whether male and female college students who value athletics show different associations between athletic interest and adjustment. 
Additionally, there is little information addressing how gender may differentially influence the relationship between perfectionistic attitudes and psychological adjustment. In the perfectionism literature, perfectionistic attitudes are described as either self or socially oriented. Self oriented perfectionism involves setting stringent self standards and evaluations to attain perfection; such individuals work hard to achieve goals. In contrast, socially oriented perfectionism involves individuals' perceived need to meet standards set by others and has strong associations with maladjustment and fear of negative evaluation (Blankstein \& Dunkley, 2002; Flett \& Hewitt, 2002a, 2002b; Hewitt \& Flett, 1991). Understanding whether perfectionism type and intensity is related to adjustment measures could assist in the potential planning of interventions to enhance students' overall well being. It is possible that a specific type of perfectionism may be more associated with adjustment among students interested in athletics.

Given that many research findings involve data collected more than a decade ago (ryckman et al., 1997, 1994; Wigfield et al., 1997), and that college aged women have increased their interest in athletics (Gill, 2001), the current study sought to address whether or not liking competition in college students who identify athletics as highly important to them, is associated with indicators of perfectionism, anxiety, and depression and whether these associations differ in men and women. As depression and anxiety are among the most commonly reported psychological concerns among college students $(18 \%$ for depression and $14 \%$ for anxiety) measurement of these concepts represents a reasonable assessment of psychological functioning (American College Health Association/National College Health Assessment web summary, 2007).

\section{Method}

\section{Participants}

This study was reviewed and received approval by the Department of Psychology Human Subjects Committee. All participants were provided written informed consent. The initial sample consisted of 349 undergraduate students attending a mid-sized Mid-Atlantic university. This sample was used to explore the psychometric properties of the Perception of Competition Scale (PCS). The final sample used to explore the questions addressed in this study consisted of 137 undergraduate students who indicated that athletics was important to them on the demographics questionnaire. Participants who rated the importance of athletics as either a 4 or 5 , on a 5 point Likert scale were selected as participants in this study.

\section{Measures}

\section{General Information Questionnaire}

This measure inquired about basic demographic information (i.e. age, sex, year in school and ethnicity) as well as how important athletics is to the participants. Additional measures selected for this study were chosen to capture the principle concepts of interest. That is, sports anxiety and its components, general measures of pathology, and a measure to help quantify the importance of sports and competition to participants.

\section{Sport Anxiety Scale (SAS)}

The SAS was used to measure sport specific anxiety. This 21-item scale measures somatic anxiety, worry and concentration disruption (Smith, Smoll, \& Schutz, 1990). The SAS has demonstrated a high degree of internal consistency (Cronbach's alpha coefficients $=.88$ for somatic anxiety, 0.82 for worry, and 0.74 for concentration disruption. As suggested by Smith, Cumming and Smoll (2006), we deleted two items from the original Concentration Disruption subscale, and one from the Somatic subscale as these items were found to cross-load in factor analytic studies of the SAS. Using the recommended scoring in the current study, Cronbach's alpha was 0.92 for somatic anxiety, 0.90 for worry and 0.80 for concentration disruption.

\section{Multidimensional Perfectionism Scale (MPS)}

The MPS is a 45-item questionnaire consisting of three subscales: self-oriented perfectionism (a tendency to strive for perfectionism for self-related motives), socially prescribed perfectionism (placing importance on being perfect to please others) and other-oriented perfectionism (setting unrealistically high standards for others). As the latter is unrelated to the purpose of this study, it was removed from the scale. The MPS is rated on a seven point Likert scale with higher scores indicating higher levels of perfectionism (Hewitt and Flett, 1991; Smith et al., 2006). The internal consistencies for this scale are typically high, ranging from 0.86 to 0.88 for self-oriented perfectionism, and 0.81 to 0.97 for socially prescribed perfectionism. The internal consistencies for this sample were .88 for self-oriented perfectionism and 0.85 for socially oriented perfectionism.

\section{State-Trait Anxiety Inventory-Trait Version (STAI-T)}

The STAI-T consists of 20 items was designed to assess participants' trait or 'general' anxiety. Each item is rated from 1 (almost never) to 4 (almost always) for how often each statement applies to them in general. The average score on this measure for a college population is approximately 38 with an approximate standard deviation of 9 . This measure also has high internal consistency (0.91) in college student samples (Knight et al., 1983). Internal consistency for the trait scale for this sample was Cronbach's $\alpha=.90$.

\section{Beck Depression Inventory (BDI)}

The BDI is a 21-item questionnaire used to provide information regarding subjects' level of depressive symptoms during the past week (Beck \& Steer 1987). Each item is rated from 0 to 3 , with higher scores reflecting greater depressive symptomatology. The internal consistency coefficient has been reported as 0.81 among non-psychiatric populations (Beck, Steer \& Garbin, 1988). Internal consistency for the BDI in this sample was Cronbach's $\alpha=.87$.

\section{Perception of Competition Scale (PCS)}

The PCS is a 38 -item questionnaire developed for this study. The items were designed to assess how much participants enjoy competition, and the positive and negative perceived impact of winning and losing. While this scale is similar to previous scales (e.g., Ryckman et al., 1996), earlier scales did not include assessment of the consequences of winning and losing. Each item was rated from 1 to 5. As the PCS was developed for this study, we first subjected this new scale to an Exploratory Factor Analysis (EFA) with oblique rotation. The results of the EFA as determined by eigenvalues (in descending order: 7.95, $5.18,2.81,1.77)$, greater than 1 and an examination of the scree 
plot, revealed the presence of four factors. However, the internal consistency for one of the factors was less than optimal ( $\alpha$ $=.54$ ) and this factor was consequently removed from consideration. Loadings of the variables on each factor are presented in Table 1. Communalities were relatively high. With a cut of $0.40,16$ of the CPQ items were retained. The three extracted factors can be described as enjoying competition, positive self-perception when winning, and negative self perception when losing, respectively. Subsequent analyses involve only these three factors of the PCS.

\section{Procedure}

Participants individually completed the packet of self-report measures. Each packet contained the measures in a pre-determined random order, with instructions to complete the measures in the order in which they were presented. As incentive for participation, each person who completed the packet of questionnaires was entered into a drawing for two randomly awarded monetary honoraria.

\section{Results}

\section{Demographic Information}

As indicated in Table 2, the sample can best be described as approximately 19 years of age, freshman in college, and primarily Caucasian (approximately 85\%) followed by Hispanic (approximately 3\%). The sample also scored within normal limits for a college sample on all instruments.

\section{Gender Differences}

To investigate gender differences, the means on each of the dependent variables were compared between genders (see Table 3). A two way (gender: female or male) MANOVA indicated no gender differences on any of the measures $\left(\mathrm{F}_{(10,106)}=\right.$ $1.46, p=.16$ ). However, to examine the interrelationship between the dependent variables by gender, we conducted a Pearson's correlation. As indicated in Table 4, among the women students, there was a significant negative correlation between enjoying competition and worry, somatic anxiety and concentration disruption on the SAS. Men evidenced a signifycant negative correlation between enjoying competition and concentration disruption on the SAS, general anxiety, and depression; for men, enjoying competition was also positively associated with self-oriented perfectionism. Positive self perceptions after winning were positively correlated with selforiented perfectionism for men and women and with sociallyoriented perfectionism only for women. As expected, negative self perceptions after losing were positively correlated for both men and women with general anxiety, depression, sociallyoriented perfectionism and worry on the SAS. Negative self perceptions after losing were also positively associated with women's self-oriented perfectionism, somatic anxiety, and concentration disruption.

Self-oriented perfectionism was positively correlated with depression but not trait anxiety for both groups. Socially-oriented perfectionism, however, was associated with trait anxiety and depression. Furthermore, self-oriented perfectionism was associated with athletic worry among males, but not females. Socially-oriented perfectionism was positively correlated with
Table 1.

PCS Loadings of all items after principal axis factor analysis with varimax rotation.

\begin{tabular}{|c|c|c|c|}
\hline \multirow{2}{*}{ Item } & \multicolumn{3}{|c|}{ Factor } \\
\hline & 1 & 2 & 3 \\
\hline 1. I like competition & 0.89 & 0.03 & -0.04 \\
\hline 2. I prepare thoroughly prior to competition & 0.33 & 0.07 & 0.34 \\
\hline 3. I have been courteous to my competitors & -0.07 & -0.00 & -0.16 \\
\hline If I lose, I will think less of myself & 0.01 & 0.22 & 0.73 \\
\hline 5. If I win, I will think more of myself & 0.02 & 0.75 & 0.09 \\
\hline 6. I am negative towards others when they win & 0.02 & 0.09 & 0.24 \\
\hline $\begin{array}{l}\text { 7. It may take a few days for me to recover after } \\
\text { a loss }\end{array}$ & -0.01 & 0.13 & 0.27 \\
\hline 8. I tend to withdraw from others following a loss & 0.01 & 0.03 & 0.29 \\
\hline I have praised others when they performed well & 0.00 & 0.03 & 0.10 \\
\hline 10. I handle losing as well as winning & -0.09 & -0.17 & -0.26 \\
\hline 11. I often feel nervous before competitions & -0.12 & 0.31 & 0.09 \\
\hline 12. I am a competitive individual & 0.79 & 0.18 & 0.05 \\
\hline 13. I get satisfaction from competing with others & 0.82 & 0.16 & 0.03 \\
\hline 14. I find competitive situations unpleasant & 0.87 & -0.02 & -0.09 \\
\hline 15. I perform my best when I am under press & 0.27 & 0.07 & 0.18 \\
\hline $\begin{array}{l}\text { 16. I am confident of doing well and showing my } \\
\text { ability }\end{array}$ & 0.36 & 0.11 & -0.39 \\
\hline 17. I'm not above cheating to win & -0.01 & 0.07 & 0.08 \\
\hline 18. I take care not to injure opponents & -0.08 & -0.07 & 0.12 \\
\hline 19. I enjoy competing against an opponent & 0.89 & 0.06 & -0.00 \\
\hline 20. I often try to out perform others & 0.51 & 0.38 & 0.15 \\
\hline $\begin{array}{l}\text { 21. When I don't win, I have told myself that I am } \\
\text { a failure }\end{array}$ & -0.08 & 0.11 & 0.75 \\
\hline 22. I try to avoid competing with others & 0.86 & 0.00 & -0.05 \\
\hline $\begin{array}{l}\text { 23. I have bounced back quickly from competitive } \\
\text { setbacks }\end{array}$ & 0.05 & 0.18 & -0.26 \\
\hline 24. If I lose, others will think less of me & -0.10 & 0.19 & 0.72 \\
\hline 5. I don't like competing against other pe & 0.90 & 0.02 & -0.07 \\
\hline 26. If I win others will think more of me & 0.06 & 0.76 & 0.22 \\
\hline $\begin{array}{l}\text { 27. I do not control my emotions well in } \\
\text { competitive situations }\end{array}$ & -0.05 & -0.06 & 0.05 \\
\hline $\begin{array}{l}\text { 28. While competing, I am unaware of } \\
\text { emotions are affecting me }\end{array}$ & -0.04 & 0.02 & 0.05 \\
\hline 29. I often "choke" under pressure & -0.37 & 0.11 & 0.16 \\
\hline 30. I take reasonable risks to succeed & 0.36 & 0.09 & -0.03 \\
\hline 31. I have acted unprofessionally to win & 0.02 & 0.05 & 0.06 \\
\hline $\begin{array}{l}\text { 32. I compete to measure myself against my } \\
\text { personal standards }\end{array}$ & 0.32 & 0.23 & 0.15 \\
\hline 33. I dread competing against other People & 0.79 & -0.02 & -0.06 \\
\hline 34. I have had dreams about winning & 0.31 & 0.24 & 0.08 \\
\hline 35. I have failed to perform in the zone & -0.13 & -0.03 & 0.20 \\
\hline $\begin{array}{l}\text { 36. Nothing feels better than winning an important } \\
\text { competition }\end{array}$ & 0.35 & 0.58 & 0.14 \\
\hline $\begin{array}{l}\text { 37. When I win, I have told myself that I am a } \\
\text { success }\end{array}$ & 0.11 & 0.74 & 0.02 \\
\hline 38. I don't mind losing as long as I perform well & -0.03 & 0.06 & -0.40 \\
\hline
\end{tabular}


Table 2 .

Participant demographic information.

\begin{tabular}{lcccc}
\hline & \multicolumn{2}{c}{ Female } & \multicolumn{2}{c}{ Male } \\
\cline { 2 - 5 } & $\mathrm{X}$ & $(\mathrm{sd})$ & $\mathrm{X}$ & $(\mathrm{sd})$ \\
\hline Age & 19.13 & $(2.80)$ & 19.32 & $(1.87)$ \\
\hline Education & $\mathrm{N}$ & $\%$ & $\mathrm{~N}$ & $\%$ \\
Freshman & 45 & 51.7 & 23 & 46.0 \\
Sophomore & 27 & 31.0 & 19 & 38.0 \\
Junior & 9 & 10.3 & 5 & 10.0 \\
Senior & 5 & 5.7 & 3 & 6.0 \\
\hline Ethnicity & $\mathrm{N}$ & $\%$ & $\mathrm{~N}$ & $\%$ \\
Caucasian & 74 & 85.1 & 43 & 86.0 \\
Hispanic & 3 & 1.1 & 1 & 2.0 \\
Asian & 0 & 1.1 & 3 & 6.0 \\
African-American & 1 & 1.1 & 1 & 2.0 \\
Other & 9 & 10.3 & 2 & 4.0 \\
\hline
\end{tabular}

Table 3.

Mean scores by gender.

\begin{tabular}{lcccc}
\hline & \multicolumn{2}{c}{ Females } & \multicolumn{2}{c}{ Males } \\
\cline { 2 - 5 } & Mean & $(\mathrm{sd})$ & Mean & $(\mathrm{sd})$ \\
\hline PCScomp & 36.50 & $(7.18)$ & 37.98 & $(5.44)$ \\
PCSpos & 15.10 & $(2.77)$ & 14.94 & $(2.82)$ \\
PCSneg & 7.66 & $(2.95)$ & 7.36 & $(2.40)$ \\
STAI-T & 40.98 & $(9.29)$ & 37.82 & $(9.67)$ \\
BDI & 10.42 & $(8.16)$ & 8.75 & $(8.03)$ \\
Selfop & 73.15 & $(15.30)$ & 68.57 & $(13.36)$ \\
Socialop & 50.54 & $(13.79)$ & 50.93 & $(9.40)$ \\
SAS-somat & 14.67 & $(5.12)$ & 13.25 & $(4.83)$ \\
SAS-worry & 16.90 & $(4.84)$ & 15.16 & $(4.11)$ \\
SAS concent & 4.80 & $(1.83)$ & 4.84 & $(1.59)$
\end{tabular}

somatic, worry and concentration disruption for women.

\section{Discussion}

Our findings suggest that college aged men and women in the current era who identify athletics as important to them differ in how enjoyment of competition is related to adjustment. In our sample, it appears that enjoyment of competition is primarily associated with decreased athletic somatic anxiety, worry, and concentration disruption among women, while it was associated with a decrease in general trait anxiety, depression, and concentration disruption among males. It is possible that for males, competition decreases general pathology, perhaps by providing them with an acceptable outlet to express negative emotions, a tendency that has been previously reported in college aged men (Flynn, Hollenstein, \& Mackey, 2010). Therefore, liking competition may actually be a protective factor for athletically identified college men. Interestingly, this was not the case for women. It may be that for athletically identified women, the benefit of enjoying competition is limited specifically to sports-related worry and somatic anxiety. Lorimer (2006), for example, found that while concern about self presentation was related to all athletes' competitive anxiety, the relationship was stronger for women. It may also be that women have alternative outlets for the expression of negative emotions and, therefore, are less generally influenced by the benefit of sports participation. In either case, the meaning of these findings deserves further exploration. As one might expect, enjoying competition was associated with decreased concentration disruption for both men and women and at the same relative strength of correlation.

An additional interesting gender difference that emerged was that among men, there was a positive association between enjoying competition and self-oriented perfectionism and between negative self-perception when losing and socially-oriented perfectionism. Among women, however, there was a positive correlation between positive self-perception when winning and self- and socially oriented perfectionism, as well as a positive correlation between negative self-perception when losing and self- and socially-oriented perfectionism. This may suggest that for men, enjoying competition is consistent with a self oriented mastery concern (self oriented perfectionism). Among women, it suggests that positive self-perception after winning is associated with a tendency towards both self-oriented mastery concerns (self oriented perfectionism) and the concern about others' evaluation of them (socially oriented perfectionism). These results are consistent with research findings that describe the pressure that women feel when they participate in activities (often male stereotyped) in which they have to prove themselves (Corbin, 1981; Heilman \& Haynes, 2005; Lorimer, 2006; Parker \& Griffin, 2002). Of some interest, males exhibited the same level of correlation between positive self-perception when winning and self-oriented perfectionism, although the correlation did not reach significance (likely due to a smaller sample of males in the current study). Males and females were both concerned about the perception of others when they reported a negative self-perception of losing, indicating that under conditions of failure, both men and women have a tendency to be concerned about what others think of them, supporting findings from research in other achievement domains about the relationship of success and failure to self esteem (Crocker et al., 2002, 2003).

It should be noted that the data is largely correlational and an experimental design would help to determine the direction of any causal relationship that exists. Furthermore, although participants were selected because they indicated that athletics was important to them, we did not obtain information regarding actual athletic membership or compare them to students not interested in athletics. It may be that those in this study were members of collegiate teams, club teams, or former high school athletes. The results could potentially be different depending on one's actual level of sports participation or interest in athletics. Additionally, the mechanism accounting for the apparent benefit of athletic identification on psychological adjustment remains unknown. It may be that enjoying competition increases one's sense of self-efficacy which, in turn, increases one's ability to manage the stress that is typically associated with elevated levels of anxiety and depression. It may also be that 
Table 4.

Correlations by gender.

\begin{tabular}{|c|c|c|c|c|c|c|c|c|c|}
\hline & 2 & 3 & 4 & 5 & 6 & 7 & 8 & 9 & 10 \\
\hline 1. PCScomp & $\begin{array}{l}0.35^{* *} \\
0.30^{* *}\end{array}$ & $\begin{array}{c}0.02 \\
-0.18\end{array}$ & $\begin{array}{c}-0.00 \\
-0.34^{*}\end{array}$ & $\begin{array}{c}0.05 \\
-0.35^{*}\end{array}$ & $\begin{array}{c}0.08 \\
0.37^{* *}\end{array}$ & $\begin{array}{l}-0.03 \\
-0.15\end{array}$ & $\begin{array}{c}-0.36^{* *} \\
-0.12\end{array}$ & $\begin{array}{c}-0.37 * * \\
-0.16\end{array}$ & $\begin{array}{l}-0.31 * * \\
-0.37 * *\end{array}$ \\
\hline 2. PCSpos & ---- & $\begin{array}{l}0.39 * * \\
0.40 * *\end{array}$ & $\begin{array}{l}0.03 \\
0.17\end{array}$ & $\begin{array}{l}0.15 \\
0.10\end{array}$ & $\begin{array}{c}0.25^{*} \\
0.25\end{array}$ & $\begin{array}{c}0.31 * * \\
0.17\end{array}$ & $\begin{array}{l}-0.00 \\
0.31^{*}\end{array}$ & $\begin{array}{l}0.03 \\
0.24\end{array}$ & $\begin{array}{l}-0.04 \\
-0.07\end{array}$ \\
\hline 3. PCSneg & ---- & ---- & $\begin{array}{l}0.48^{* *} \\
0.44^{* *}\end{array}$ & $\begin{array}{l}0.51^{* *} \\
0.50^{* *}\end{array}$ & $\begin{array}{c}0.41 * * \\
0.22\end{array}$ & $\begin{array}{l}0.62 * * \\
0.59 * *\end{array}$ & $\begin{array}{c}0.19^{*} \\
0.17\end{array}$ & $\begin{array}{l}0.46^{* *} \\
0.57^{* *}\end{array}$ & $\begin{array}{c}0.25^{*} \\
0.19\end{array}$ \\
\hline 4. STAI-T & ---- & ---- & ---- & $\begin{array}{l}0.61^{* *} \\
0.74^{* *}\end{array}$ & $\begin{array}{l}0.18 \\
0.08\end{array}$ & $\begin{array}{c}0.38^{* *} \\
0.35^{*}\end{array}$ & $\begin{array}{c}0.24 * \\
0.43 * *\end{array}$ & $\begin{array}{l}0.49^{* *} \\
0.34 * *\end{array}$ & $\begin{array}{c}0.36 * * \\
0.22\end{array}$ \\
\hline 5. BDI & ---- & ---- & ---- & --- & $\begin{array}{l}0.44 * * \\
0.37 * *\end{array}$ & $\begin{array}{c}0.58^{* *} \\
0.33^{*}\end{array}$ & $\begin{array}{c}0.18 \\
0.43^{* *}\end{array}$ & $\begin{array}{l}0.39^{* *} \\
0.44^{* *}\end{array}$ & $\begin{array}{c}0.33^{* *} \\
0.21\end{array}$ \\
\hline 6. selfp & ---- & ---- & ---- & ---- & ---- & $\begin{array}{l}0.66 * * \\
0.47^{* *}\end{array}$ & $\begin{array}{c}-0.02 \\
0.18\end{array}$ & $\begin{array}{c}0.10 \\
0.29^{*}\end{array}$ & $\begin{array}{c}0.02 \\
-0.19\end{array}$ \\
\hline 7. socialp & ---- & ---- & ---- & ---- & ---- & ---- & $\begin{array}{c}0.25^{*} \\
0.19\end{array}$ & $\begin{array}{l}0.33 * * \\
0.40^{* *}\end{array}$ & $\begin{array}{c}0.41 * * \\
0.14\end{array}$ \\
\hline 8. somatic & ---- & --- & ---- & ---- & ---- & ---- & ---- & $\begin{array}{l}0.62 * * \\
0.37 * *\end{array}$ & $\begin{array}{c}0.38 * * \\
0.14\end{array}$ \\
\hline 9. worry & ---- & ---- & ---- & ---- & ---- & ---- & ---- & ---- & $\begin{array}{c}0.46^{* *} \\
0.30^{*}\end{array}$ \\
\hline 10. concentrat & ---- & --- & ---- & ---- & ---- & ---- & ---- & ---- & ---- \\
\hline
\end{tabular}

participation in athletics and athletic identification increases available social support which helps to improve psychological adjustment (Csikszentmihalyi, 1982). Such issues will need to be explored in future studies. Nonetheless, the results from this study clearly suggest that men and women who value athletics are differentially impacted by their enjoyment of competition, although there was some positive benefit for both groups. These results, if supported in future research, suggests that promoting athletic participation and enjoyment will produce psychological benefits in the future. It may be that encouraging sports participation in school settings, community organizations, or through parental involvement teaches a specific set of coping skills (e.g., coping with adversity) that can have a lasting impact on the psychological development of a child.

\section{References}

American College Health Association. (2007). National College Health Assessment web summary. Available at http://www.acha-ncha.org/data.

Arnett, J. J. (2000). Emerging adulthood: A theory of development from the late teens through the twenties. American Psychologist, 55, 469-480. doi:10.1037/0003-066X.55.5.469

Arnett, J. J. (2007). Adolescence and emerging adulthood: A cultural approach (3rd Edition). Upper Saddle River, NJ: Prentice Hall.

Beck A. T., \& Steer, R. (1987). Manual for the Beck Depression Inventory. San Antonio, Tex: Psychological Corporation.

Beck, A. T., Steer, R. A., \& Garbin, M. G. (1988). Psychometric properties of the Beck Depression Inventory: Twenty-five years of evaluation. Clinical Psychology Review, 8, 77-100. doi:10.1016/0272-7358(88)90050-5

Blankstein, K. R., \& Dunkley, D. M. (2002). Evaluative concerns, self-critical, and personal standards perfectionism: A structural equation modeling strategy. In G. L. Flett \& P. L. Hewitt, (Eds.). Perfectionism: Theory, Research and Treatment (pp. 285-315). Washington, DC: American Psychological Association.

Carodine, K., Almond, K. F., \& Gratto, K. K. (2001). College student athlete success both in and out of the classroom. New Directions for Student Services, 93, 19-33. doi:10.1002/ss.2

Corbin, C. B. (1981). Sex of subject, sex of opponent, and opponent ability as factors affecting self-confidence in a competitive situation. Journal of Sports Psychology, 4, 265-270.

Crocker, J., Karpinski, A., Quinn, D. M., \& Chase, S. (2003). When grades determine self-worth: Consequences of contingent self-worth for male and female engineering and psychology majors. Journal of Personality and Social Psychology, 85, 507-516. doi:10.1037/0022-3514.85.3.507

Crocker, J., Sommers, S. R., \& Luhtanen, R. K. (2002). Hopes dashed and dreams fulfilled: Contingencies of self-worth and admissions to graduate school. Personality and Social Psychology Bulletin, 28, 1275-1286. doi: $10.1177 / 01461672022812012$

Csikszentmihalyi, M. (1982). The Value of Sports. In John T. Parington, Terry Orlicke, \& John H. Salmela (Eds.). Sports in Perspective. Ottawa, Ontario, Canada: Coaching Association of Canada.

Eccles, J. S. \& Harold, R. D. (1991). Gender differences in sport involvement: Applying the Eccles' expectancy-value model, Journal of Applied Sport Psychology, 3, 7-35. doi:10.1080/10413209108406432

Eccles, J.,Wigfield, A., Harold, R., \& Blumenfeld, P. (1993). Age and gender differences in children's self and task perceptions during elementary school. Child Development, 64, 830-847. doi:10.2307/1131221

Fletcher, T. B., Benshoff, J. M., \& Richburg, M. J. (2003). A systems approach to understanding and counseling college student-athletes. Journal of College Counseling, 6, 35-45.

Flett, G. L., \& Hewitt, P. L. (2002a). Perfectionism and maladjustment: An overview of theoretical, definitional, and treatment issues. In Flett, G. L., and Hewitt, P. L. (Eds), Perfectionism: Theory, Research and Assessment. Washington, DC: American Psychological Association.

Flett, G. L., \& Hewitt, P. L. (2002b). Perfectionism Theory, Research and Assesment. Washington, DC: American Psychological Association.

Flynn, J. F., Hollenstein, T., \& Mackey, A. (2010). The effect of suppressing and not accepting emotions on depressive symptoms: Is suppression different for men and women? Personality and Individual Differences, 49, 582-586. doi:10.1016/j.paid.2010.05.022

Fredricks, J. A., \& Eccles, J. S. (2005). Family socialization, gender, 
and sport motivation and involvement. Journal of Sport and Exercise Psychology, 27, 3-31.

Gill, D. L. (2001). Sports and athletics. In J. Worell (senior Ed.), Encyclopedia of Women and Gender (pp.1091-1100). San Diego: Academic Press.

Heilman, M. E., \& Haynes, M. C. (2005). No credit where credit is due: Attributional rationalization of women's success in male-female teams. Journal of Applied Psychology, 90, 905-916. doi:10.1037/0021-9010.90.5.905

Hewitt, P., \& Flett, G. (1989). The Multidimensional Perfectionism Scale: Development and validation. Canadian Psychology, 30, 339.

Hewitt, P. L. \& Flett, G. L. (1991). Perfectionism in the self and social contexts: Conceptualization, assessment, and association with psycho-pathology. Journal of Personality and Social Psychology, 60, 456-470. doi:10.1037/0022-3514.60.3.456

Knight, R. G., Waal-Manning, H. J., \& Spears, G. F. (1983). Some norms and reliability data for the State-Trait Anxiety Inventory and the Zung Self-Rating Depression Scale. British Journal of Clinical Psychology, 22, 245-249.

Lorimer, R. (2006). The relationship between self-presentational concerns and competitive anxiety: The influence of gender. International Journal of Sports Psychology, 37, 317-329.

Melendez, M. C. (2006). The influence of athletic participation on the college adjustment of freshman and sophomore student athletes. College Student Retention, 8, 39-55. doi:10.2190/8GLY-G974-V7FM-E1YD

Montgomery, M. J., \& Côté, J. E. (2003). College as a transition to adulthood. In G. R. Adams \& M. D. Berzonsky (Eds.), Blackwell handbook of adolescence (pp. 149-172). Malden, MA: Blackwell.

Parker, S. K., \& Griffin, M. A. (2002). What is so bad about a little name-calling? Negative consequences of gender harassment for overperformance demands and distress. Journal of Occupational Health Psychology, 7, 195-210. doi:10.1037/1076-8998.7.3.195

Ryckman, R. M., Libby, C. R., van den Borne, B., Gold, J. A., \& Lindner, M. A. (1997). Values of hypercompetitive and personal development competitive individuals. Journal of Personality Assessment,
69, 271-283. doi:10.1207/s15327752jpa6902_2

Ryckman, R. M., Hammer, M., Kaczor, L. M., \& Gold, J. A. (1996). Construction of a personal development competitive attitude scale. Journal of Personality Assessment, 66, 374-385. doi:10.1207/s15327752jpa6602 15

Ryckman, R. M., Thornton, B., \& Butler, J. C. (1994). Personality correlates of the hypercompetitive attitude scale: Validity test of Horney's theory of neurosis. Journal of Personality Assessment, 62, 84-94. doi:10.1207/s15327752jpa6201 8

Smith, R. E., Cumming, S. P., \& Smoll, F. L. (2006). Factorial integrity of the Sport Anxiety Scale: A methodological note and revised scoring recommendations. Journal of Sport and Exercise Psychology, 28, 109-112.

Smith, R. E., Smoll, F. L., \& Schutz, R. W. (1990). Measurement and correlates of sport-specific cognitive and somatic trait anxiety: The Sport Anxiety Scale. Anxiety Research, 2, 263-280.

Spielberger, C. D., Gorsuch, R. L., \& Lushene. R. E. (1970). Manual for the State-Trait Anxiety Inventory. Palo Alto, CA: Consulting Psychologists Press.

Steiner, H., McQuivey, R. W., Pavelski, R., Pitts, T., \& Kraemer, H. (2000). Adolscents and sports: Risk or benefit? Clinical Pediatrics, 39, 161-166. doi:10.1177/000992280003900304

Weiss, K. (2004, November), "Framework for performance measurement", Agency for Health Care Policy and Research. Invitational Meeting on Performance Measurement, Data Aggregation, and Reporting, available at: www.ahcpr.gov/qual//performance/performance.pdf,.

Wigfield, A., Eccles, J. S., Yoon, K. S., Harold, R., Arbreton, A. Freedman-Doan, C., \& Blumenfeld, P. C. (1997). Changes in children's competence beliefs and subjective task values across the elementary school years: A three-year study. Journal of Educational Psychology, 89, 451-469. doi:10.1037/0022-0663.89.3.451

Wong, E., Lox, C., \& Clark, S. (1993). Relation between sport context, competitive trait anxeity, perceived ability, and self-presentation confidence. Perceptual and Motor Skills, 76, 847-850. 